\title{
Reproductive Biology Studies in Nerium Cultivars (Nerium oleander L.)
}

\author{
M. Parashuram ${ }^{1 *}$, K.R. Rajadurai ${ }^{1}$, S. Haripriya ${ }^{2}$ and A. John Joel ${ }^{3}$ \\ ${ }^{1}$ Department of Floriculture and Landscaping, TNAU Coimbatore-641003, TN, India \\ ${ }^{2}$ Department of Nano Science and Technology, TNAU Coimbatore-641003, TN, India \\ ${ }^{3}$ Centre for Plant Breeding and Genetics, TNAU Coimbatore-641003, TN, India
}

*Corresponding author

\begin{tabular}{|l|}
\hline Ke y w o r d s \\
Reproductive \\
biology, Stigma \\
receptivity, \\
Anthesis, Anther \\
dehiscence, Pollen \\
Viability
\end{tabular}

\section{Introduction}

Nerium (Nerium oleander L.) is an evergreen
shrub or small tree in the dogbane family
Apocynaceae (Kiran and Prasad, 2014; Yadav
et.al, 2013). The Apocynaceae is a diverse and
species rich family in the order Gentianales.

Nerium (Nerium oleander L.) is an evergreen
shrub or small tree in the dogbane family
Apocynaceae (Kiran and Prasad, 2014; Yadav
et.al, 2013). The Apocynaceae is a diverse and
species rich family in the order Gentianales.

Nerium (Nerium oleander L.) is an evergreen
shrub or small tree in the dogbane family
Apocynaceae (Kiran and Prasad, 2014; Yadav
et.al, 2013). The Apocynaceae is a diverse and
species rich family in the order Gentianales.

Nerium (Nerium oleander L.) is an evergreen
shrub or small tree in the dogbane family
Apocynaceae (Kiran and Prasad, 2014; Yadav
et.al, 2013). The Apocynaceae is a diverse and
species rich family in the order Gentianales.

Nerium (Nerium oleander L.) is an evergreen
shrub or small tree in the dogbane family
Apocynaceae (Kiran and Prasad, 2014; Yadav
et.al, 2013). The Apocynaceae is a diverse and
species rich family in the order Gentianales.

\section{A B S T R A C T}

The objective of this work was to study the reproductive biology in four nerium cultivars. Anthesis, anther dehiscence, stigma receptivity, flower and fruit morphology, pollen morphology and production, ovule production and pollen ovule ratio were studied. Anthesis in nerium cultivars started from 5.30 a.m. and reached the peak by 6.30 a.m. except in yellow cultivar (6.30 to $7.30 \mathrm{am}$ ). Nerium flowers are protandrous in nature and the anthers dehisced by longitudinal slit just before the anthesis. Anther dehiscence started at 5.30 a.m. and maximum anther dehisce was observed between 5.30 to 6.30 am during 2016 and the similar trend was found in 2017. The maximum mean pod set per cent (78, 70,74 and 72) was observed on the day of anthesis, when the flowers were crossed between 5.30 and 11.30 a.m. at one hour interval in all the nerium cultivars. Pod set per cent indicated that high stigma receptivity was recorded on the day of anthesis. For completing the flowering phase of single flower, the highest number of days was recorded in Red cultivar (29.66) followed by Pink cultivar (28.20) and the least days in Yellow cultivar (27.53). Pink cultivar recorded maximum number of (21.86) inflorescence per plant, (70.86) number of flowers per inflorescence, $(5.04 \mathrm{~cm})$ flower diameter, $(2.15 \mathrm{~cm})$ corolla tube length, $(1.40 \mathrm{~cm})$ length of gynoecium, $(8.81 \mathrm{~mm})$ fruit diameter and $(279.00)$ number seeds per fruit. Among the cultivars investigated, maximum equatorial length $(48.98 \mu \mathrm{m})$ and polar length $(42.65 \mu \mathrm{m})$ recorded from Yellow cultivar. Presence of bicarpellary ovary, with numerous ovules up to 386 and pollen grains up to14600 in Pink cultivar were found in a single flower of nerium. The results obtained from the present study on reproductive biology can aid in planning better crosses and establishment of nerium breeding programs using compatible cultivars.
The family has a widespread distribution throughout tropical and temperate regions (Barrios and Koptur, 2011). Nerium oleander L. is widely cultivated that no precise region of origin has been identified, though South West Asia has been suggested. It typically occurs around dry stream beds. In India 
nerium distributed throughout the country but commercial cultivation takes place in Tamil Nadu only. Nerium grows to 2-6 m tall, with erect stems that spread outward as they mature. Leaves are 10 to $22 \mathrm{~cm}$. long, narrow, acute and have a prominent mid rib, are "leathery" in texture and usually arise in groups of three from the stem. The plant produces terminal flower heads, usually pink or white (Kiran and Prasad, 2014). Neriumis an ornamental plant used in the urban landscaping due to its spectacular flowering which can have different colorations as the variety and its resistance to long drought periods (Albornoz et al., 2014).

In Tamil Nadu, nerium is used for various purposes like ornamental plants in garden, religious purpose and garlands. Now days in India neruim cultivation gaining more importance due to its wide utility but no systematic research has been carried out. The aim of this study was to describe the reproductive biology in nerium cultivars under Coimbatore condition of India.

\section{Materials and Methods}

\section{Plant material and study site}

The study was conducted during 2016-2017 to study the reproductive biology in nerium cultivars at Department of Floriculture and Landscaping, Horticulture College and Research Institute, Tamil Nadu Agricultural University, Coimbatore. The four cultivars of nerium was collected different parts of Tamil Nadu. Red cultivar from Salem, White cultivar from Dindigul, Pink cultivars from Nilakkottai and Yellow cultivars from Thovalai. The wellestablished ground layered plants were used for plating. In a fortnight duration, all the plants were established well. Flower initiation occurred two months after planting and all the flowers were nipped off regularly until the plants were reaches four month old.

\section{Phenology and floral biology}

The time of anthesis (complete opening of flower) was recorded when the tagged flower buds open. Anthesis time was observed at two times to confirm the exact flower opening time at October 2016 and April 2017. The time of anther dehiscence was recorded in the tagged flower buds. Anther dehiscence was observed two times to confirm the exact anther dehiscence time at October 2016 and April 2017. To assess the time of the stigma receptivity, controlled pollination of flowers was carried at on the day of anthesis and one day after anthesis as the method suggested by (Anandhi and Rajamani, 2012) in glory lily. Number of days taken for completion of flowering phage (Single flower) was observed. The inflorescences were tagged just after initiation of inflorescence and number of days was observed sequentially until the withering of first flower in the inflorescence.

The number of inflorescence per plant and total number of flowers per inflorescence was counted at six month after planting. Flower diameter was measured in fully opened flowers with the help of scale. Corolla tube length was measured from the point of attachment of pedicel to the top of the petal.

The pedicel length was measured from the point of attachment at the stem to the base of bud with the help of scale. The mean was calculated and expressed in centimetre (cm).The length of androecium was measured from the base of filament to the tip of the extended hairs of the anther. The length of gynoecium was measure from the point of attachment of ovary to tip of the stigma. The fruit length was measured with the help of scale. The mean was calculated and expressed in centimetre $(\mathrm{cm})$. The fruit diameter was measured with the help of digital Vernier calliper. The number of seeds fruit ${ }^{-1}$ was recorded by counting the seeds. 


\section{Pollen morphology and number of pollen grains}

Pollen morphology was observed the method suggested by Radovic et al., (2016). Equivalent length, polar length, equivalent to polar length ratio, exine length and intine length were observed in the light microscope and photo were taken with help of camera attached to the microscope using the software Scopel image 9 exe. Pollen production anther ${ }^{1}$ was estimated using Haemocytometer method as suggested by Sathiamoorthy (1973). Pollens were collected with the help of needle in a vial containing $2.5 \mathrm{ml}$ of distilled water and a drop of teepol for obtaining a good suspension of pollen grains in water. The contents were thoroughly shaken and two drops of it were pipetted out and placed on each of the two "counting chambers" of a "Spencer bright line Haemocytometer". The number of pollen grains in each of the eight "corner squares" was recorded. The average number of pollen grains per square multiplied by 2500 gave the quantity of pollens per anther. Number of pollen grains per flower was also calculated by followed the same method as above mentioned. Instead of collecting pollen grains from single anther pollen grains was collected from all five anther.

\section{Number of ovules and pollen ovule ratio}

Thirty days after the pollination the number of ovules was observed. The small fruit was taken and longitudinal cross section was given, two locules are separated and ovules were counted under the stereomicroscope. Photo were captured with software and camera attached with microscope, Lica 5.1. Pollen ovules ratio was calculated by dividing the number of pollen grains with number of ovule counted. The value was expressed in the ratio.

The statistical analysis was done by adopting the standard procedures of Panse and
Sukhatme (1985). The critical difference was worked out at five per cent (0.05) probability. Analysis was carried out with AGRES software package and MS Excel ${ }^{\circledR}$ spreadsheet.

\section{Results and Discussion}

\section{Phenology and floral biology}

It is evident from the data (Table 1) that highest per cent of 75.38, 56.43, 52.78, flower opening observed at 5.30 to 6.30 a.m. in Red, Pink and White cultivar respectively but in yellow cultivar a steady flower opening observed between 5.30 to 8.30 a.m. in between that period highest per cent 34.89 flower opening observed at 6.30 to $7.30 \mathrm{am}$ in 2016. The similar trend was found in 2017. The highest flower opening per cent $(82.00$, $53.00,58.32$ ) observed between 5.30 to 6.30 a.m. in Red White and Pink cultivars respectively and in Yellow cultivar the highest per cent of flower opening (36.27) was observed between 6.30 to 7.30 a.m. The lowest flower opening per cent $(7.22,5.02$, 3.81 and 6.36) recorded between 8.30 to 9.30 am in all the cultivars during 2016 and in 2017 the lowest per cent $(3.83,5.25,3.34$ and 9.12) of flower opening recorded at 8.30 to 9.30 a.m. In general, the bud opening in nerium cultivars started from 5.30 a.m. and reached the peak at 6.30 a.m. except yellow it is in 6.30 to $7.30 \mathrm{am}$. It has started declining and minimum per cent flower buds opening recorded between 8.30 to 9.30 a.m. In the process of normal flowering, the first splitting of the bud is referred as bud opening followed by anthesis. The bud opening or anthesis varies from crop to crop and their species. They are also greatly influenced by environmental factors such as humidity, light, temperature and rainfall. Knowledge on anthesis and mode of pollination is desirable in any crop improvement programme especially for making successful crosses Anandhi and Rajamani, (2012). These results 
are in conformation with findings of Barrios and Koptur (2011) in Angadenia berteroi that flowers opened before sunrise 5.30 a.m. This was in agreement with the report of Kulloli and Sreekala (2009) and Sihag and Wadhwa (2011) in Rauvolfia micrantha and Rauvolfia serpentina (Linn.) respectively. In glory lilly, (Gloriosa superba) maximum mean percentage of flower bud opening in a day was observed between 8.30 to 9.30 a.m. (52.00 per cent) followed by 7.30 to 8.30 a.m. (30.00 per cent) Anandhi (2012) (Table 2).

The highest per cent $(83.59,67.92,75.79$ and 56.44) of anther dehiscence was occurred at 5.30 to 6.30 a.m. in Red, White, Pink and Yellow cultivars respectively during 2016. The similar observations were recorded during the year 2017. The highest per cent of anther dehiscence (86.07, 73.12, 75.52, and 57.03) was occurred at 5.30 to 6.30 a.m. in Red, White, Pink and Yellow cultivars respectively.

The lowest anther dehiscence per cent (3.78, 3.93, 0.93 and 2.05) was occurred between 8.30 to 9.30 a.m. in all the cultivars during 2016 and similar observations were recorded in 2017 with the lowest per cent $(2.33,2.50$, 1.43 and 4.79) was occurred between 8.30 to 9.30 a.m. in all the nerium cultivars. Nerium flowers are protandrous in nature and the anthers dehisced by longitudinal slit just before the anthesis (Figure 1).

These findings are in accordance with the observation made by Kulloli and Sreekala (2009) in Rauvolfia micrantha who stated that anther dehiscence occurred around 6.30a.m. This indicated that nerium is photosensitive, anthesis and anther dehiscence corresponded to the plants exposure to sunlight. There upon (after 7.30 a.m.), as the intensity of sunlight is more, the anthesis and anther dehiscence was slow down. Mamatha (1989) and Anandhi and Rajamani (2012) reported the similar observation in glory lilly (Fig. 2).
The results pertaining to the time of stigma receptivity are presented in Table 3 . It is evident from the data that the mean pod set per cent (78, 70, 74 and 72) was observed on the day of anthesis, when the flowers were crossed between 5.30 to $11.30 \mathrm{a} . \mathrm{m}$. at one hour interval in all the nerium cultivars. Pod set per cent indicating that high stigma receptivity was recorded on the day of anthesis. Lowest stigma receptivity was observed in flowers pollinated one day after anthesis in all the nerium cultivars. It indicated the maximum receptiveness of stigma during anthesis. This results were in conformation with findings of Herrera (1989) reported that at flower opening, pollen has been shed and the stigma is fully receptive, so that the flower may both donate and receive pollen. In general, the percentage of pod set was higher in the early morning hours (7.00 to 8 a.m.), irrespective of the pollination done on different days. In general, the stigma remains receptive for two days viz. on the day of anthesis and one day after anthesis. This is in agreement with observation made by Anandhi and Rajamani (2013) in glory lilly.

The data on number of days taken for completion of flowering phase of (single flower) are presented in Table 4 and figure 3. The data reveals that statistically significant difference with respect number of days taken for completion of flowering phase (Single flower) in nerium cultivars was observed. It is evident from the data that highest number of 6.40 days was taken for inflorescence initiation to bud initiation in White cultivar which was on par with Red (6.33) and Yellow cultivars (6.38) and the least day was recorded in Pink cultivar (5.73). Number of days for bud initiation to balloon stage was recorded highest (12.00) in Red cultivar followed by Pink cultivar (11.00) and the least in white cultivar (10.80). All the cultivars of nerium took only a day to change from balloon stage to flower opening. From anthesis to withering 
of flowers maximum days was recorded in Pink cultivar (7.46) and followed by Red cultivar (7.33) and the least days recorded in White cultivar (6.73). For completing the flowering phase of single flower the highest number of days was recorded in Red cultivar (29.66) followed by Pink cultivar (28.20) and the least days in Yellow cultivar (27.53).In general, nerium plant will take five to six days from inflorescence initiation to bud initiation, ten to twelve days from bud initiation to balloon stage, six to seven days from anthesis to withering of corolla and twenty seven to thirty days for completion of flowering phase. These observations were in line with findings of Anandhi and Rajamani (2013) in glory lilly. In nerium similar observation made by Herrera (1989) stated that after anthesis of nerium flower take three to seven days for obsession of corolla. Kulloli and Shreekala (2009) made the similar observation in Rauvolfia micrantha reported that the flower bud stake 10-15 days from initiation to full bloom. The average life-span of each individual flower was recorded to be 2-4 days after blooming.

The results pertaining to number of inflorescence per plant and number of flowers per inflorescence presented in Table 5. It is evident from the data that number of inflorescence per plant and number of flowers per inflorescence varied significantly among cultivars at six month after planting. The highest number of inflorescences per plant (21.86) was observed in Pink cultivar at six month after planting followed by White cultivar (17.53) at six month after planting while least observed in Yellow cultivar (12.53) at six month after planting. The highest number of flowers per inflorescence (70.86) was recorded in Pink cultivar at six month after plating followed by in Red cultivar (68.93) and the least number of flowers inflorescence ${ }^{-1}$ (64.03) was recorded in White cultivar at six month after planting.
Similar observation made by Herrera (1989) in nerium reported that a medium sized plant (about $2 \mathrm{~m}$ of diameter and $2 \mathrm{~m}$ height) may produce from eight to more than 100 inflorescences. These are corymbs that, when large have 3-5 lateral branches and may produce between 12 and 44 flowers. This finding is in accordance with observation made by Sihag and Wadhwa (2011) in Rauvolfia serpentina reported that the number of inflorescences per plant ranged from 17 to 63 and flowers in the inflorescences ranged from 36 to 54. Data presented in Table 6 revealed that the performance of nerium cultivars for flower diameter, corolla tube length and pedicel length. Cultivars differed significantly with respect to flower diameter and corolla tube length. Among the cultivars the highest flower diameter of $5.04 \mathrm{~cm}$ was recorded in Pink cultivar followed by Red cultivar $(4.84 \mathrm{~cm})$ and the least flower diameter recorded in White cultivar $(4.71 \mathrm{~cm})$.

Pink cultivar recorded highest corolla tube length of $2.15 \mathrm{~cm}$ followed by the Red cultivar $(1.98 \mathrm{~cm})$. The least corolla tube length of $1.76 \mathrm{~cm}$ was recorded in White cultivar. It is evident from the data that maximum pedicel length of $0.75 \mathrm{~cm}$ was recorded in Pink cultivar followed by the White cultivar $(0.66 \mathrm{~cm})$. The least pedicel length was recorded in Yellow cultivar $(0.61 \mathrm{~cm})$. This was in accordance with observation made by Herrera (1989) and Kiran and Prasad (2014) in nerium.

Length of androecium showed significant differences among the nerium cultivars as shown in Table 7. Among the cultivars highest androecium length of $2.59 \mathrm{~cm}$ was recorded in the Red cultivar followed by in white cultivar $(2.54 \mathrm{~cm})$. The least length of androecium was recorded in Yellow cultivar $(2.44 \mathrm{~cm})$. Among the cultivars highest gynoecium length of 1.40 $\mathrm{cm}$ was recorded in Pink cultivar followed by Yellow cultivar with $1.30 \mathrm{~cm}$ while the least in White cultivar with $1.24 \mathrm{~cm}$. 
Int.J.Curr.Microbiol.App.Sci (2019) 8(7): 377-392

Table.1 Time of anthesis in nerium (Nerium oleander L.) cultivars

\begin{tabular}{|c|c|c|c|c|c|c|c|c|}
\hline \multirow{2}{*}{ Cultivars } & \multicolumn{8}{|c|}{ Flowers opening at hours intervals (\%) } \\
\cline { 2 - 9 } & $\mathbf{5 . 3 0}-\mathbf{6 . 3 0} \mathbf{~ a m}$ & $\mathbf{6 . 3 0 - 7 . 3 0} \mathbf{~ a m}$ & $\mathbf{7 . 3 0 - 8 . 3 0} \mathbf{a m}$ & $\mathbf{8 . 3 0 - 9 . 3 0}$ am \\
\cline { 2 - 9 } & $\mathbf{2 0 1 6}$ & $\mathbf{2 0 1 7}$ & $\mathbf{2 0 1 6}$ & $\mathbf{2 0 1 7}$ & $\mathbf{2 0 1 6}$ & $\mathbf{2 0 1 7}$ & $\mathbf{2 0 1 6}$ & $\mathbf{2 0 1 7}$ \\
\hline \multirow{2}{*}{ Red } & 75.38 & 82.00 & 7.62 & 7.78 & 9.77 & 6.74 & 7.22 & 3.83 \\
& $*(60.25)$ & $(64.33)$ & $(16.01)$ & $(14.15)$ & $(18.15)$ & $(15.01)$ & $(5.29)$ & $(8.97)$ \\
\hline White & 52.78 & 53.00 & 36.03 & 35.35 & 6.15 & 5.70 & 5.02 & 5.25 \\
& $(46.59)$ & $(47.16)$ & $(36.74)$ & $(36.47)$ & $(14.34)$ & $(13.80)$ & $(15.50)$ & $(12.64)$ \\
\hline Pink & 56.43 & 58.32 & 33.93 & 33.86 & 5.81 & 6.33 & 3.81 & 3.34 \\
& $(48.69)$ & $(48.70)$ & $(35.76)$ & $(35.58)$ & $(13.94)$ & $(14.56)$ & $(11.50)$ & $(11.35)$ \\
\hline Yellow & 24.43 & 30.45 & 34.89 & 36.27 & 34.30 & 27.46 & 6.36 & 9.12 \\
& $(29.60)$ & $(31.37)$ & $(36.20)$ & $(37.03)$ & $(35.90)$ & $(31.59)$ & $(14.55)$ & $(17.38)$ \\
\hline Mean & 52.26 & 55.94 & 28.12 & 28.32 & 14.01 & 11.56 & 5.60 & 5.39 \\
\hline SEd & 0.65 & 0.69 & 0.47 & 0.50 & 0.59 & 0.63 & 2.59 & 1.94 \\
\hline CD & 1.45 & 1.51 & 1.03 & 1.09 & 1.29 & 1.37 & 5.64 & 4.23 \\
$(\mathbf{p = 0 . 0 5 )}$ & & & & & & & & \\
\hline
\end{tabular}

*Percentage values are converted to arc sin value for analysis of variance

Table. 2 Time of anther dehiscence in nerium (Nerium oleander L.) cultivars

\begin{tabular}{|c|c|c|c|c|c|c|c|c|}
\hline \multirow[t]{3}{*}{ Cultivars } & \multicolumn{8}{|c|}{ Anther dehiscence at hour's intervals (\%) } \\
\hline & \multicolumn{2}{|c|}{$5.30-6.30 \mathrm{am}$} & \multicolumn{2}{|c|}{ 6.30-7.30 am } & \multicolumn{2}{|c|}{ 7.30-8.30 am } & \multicolumn{2}{|c|}{ 8.30-9.30 am } \\
\hline & 2016 & 2017 & 2016 & 2017 & 2016 & 2017 & 2016 & 2017 \\
\hline Red & $\begin{array}{c}83.59 \\
*(65.73)\end{array}$ & $\begin{array}{c}86.07 \\
(68.14)\end{array}$ & $\begin{array}{c}7.85 \\
(16.24)\end{array}$ & $\begin{array}{c}7.99 \\
(16.41)\end{array}$ & $\begin{array}{c}4.96 \\
(12.89)\end{array}$ & $\begin{array}{c}4.09 \\
(11.55)\end{array}$ & $\begin{array}{c}3.78 \\
(11.21)\end{array}$ & $\begin{array}{c}2.33 \\
(8.68)\end{array}$ \\
\hline White & $\begin{array}{c}67.92 \\
(57.86)\end{array}$ & $\begin{array}{c}73.12 \\
(58.77)\end{array}$ & $\begin{array}{c}21.82 \\
(27.84)\end{array}$ & $\begin{array}{c}18.09 \\
(25.16)\end{array}$ & $\begin{array}{c}5.73 \\
(13.65)\end{array}$ & $\begin{array}{c}5.47 \\
(13.43)\end{array}$ & $\begin{array}{c}3.93 \\
(11.26)\end{array}$ & $\begin{array}{c}2.50 \\
(8.67)\end{array}$ \\
\hline Pink & $\begin{array}{c}75.79 \\
(59.06)\end{array}$ & $\begin{array}{c}75.52 \\
(60.35)\end{array}$ & $\begin{array}{c}17.68 \\
(24.86)\end{array}$ & $\begin{array}{c}16.24 \\
(23.21)\end{array}$ & $\begin{array}{c}5.57 \\
(13.63)\end{array}$ & $\begin{array}{c}6.68 \\
(14.96)\end{array}$ & $\begin{array}{c}0.93 \\
(5.29)\end{array}$ & $\begin{array}{c}1.43 \\
(6.84)\end{array}$ \\
\hline Yellow & $\begin{array}{c}56.44 \\
(48.70)\end{array}$ & $\begin{array}{c}57.03 \\
(49.01)\end{array}$ & $\begin{array}{c}32.72 \\
(34.88)\end{array}$ & $\begin{array}{c}29.55 \\
(32.92)\end{array}$ & $\begin{array}{c}8.68 \\
(17.07)\end{array}$ & $\begin{array}{c}8.00 \\
(16.39)\end{array}$ & $\begin{array}{c}2.05 \\
(7.97)\end{array}$ & $\begin{array}{c}4.79 \\
(12.28)\end{array}$ \\
\hline Mean & 70.94 & 72.94 & 20.02 & 17.97 & 6.24 & 6.06 & 2.67 & 2.76 \\
\hline SEd & 9.71 & 0.63 & 0.58 & 0.49 & 1.24 & 0.75 & 1.49 & 1.62 \\
\hline $\begin{array}{c}\text { CD } \\
(p=0.05)\end{array}$ & NS & 1.38 & 1.26 & 1.06 & 2.71 & 1.64 & 3.26 & 3.53 \\
\hline
\end{tabular}

* Percentage values are converted to arc sin value for analysis of variance 
Table.3 Time of stigma receptivity in nerium (Nerium oleander L.) cultivars

\begin{tabular}{|c|c|c|c|c|c|c|c|c|}
\hline \multirow[t]{2}{*}{ Cultivars } & \multirow[t]{2}{*}{ Time (am) } & \multirow[b]{2}{*}{$\begin{array}{c}\text { Total No. } \\
\text { of } \\
\text { flowers } \\
\text { crossed } \\
\text { each day }\end{array}$} & \multicolumn{3}{|c|}{ On the day of anthesis } & \multicolumn{3}{|c|}{ Day after anthesis } \\
\hline & & & $\begin{array}{l}\text { No. of } \\
\text { pod set }\end{array}$ & $\begin{array}{c}\% \text { of } \\
\text { pod set }\end{array}$ & $\begin{array}{c}\text { Mean } \\
(\%)\end{array}$ & $\begin{array}{c}\text { No. } \\
\text { of } \\
\text { pod } \\
\text { set }\end{array}$ & $\begin{array}{c}\% \\
\text { of } \\
\text { pod } \\
\text { set }\end{array}$ & $\begin{array}{l}\text { Mean } \\
(\%)\end{array}$ \\
\hline \multirow[t]{5}{*}{ Red } & $6.30-7.30$ & 10 & 7 & 70 & \multirow[t]{5}{*}{78} & 2 & 20 & \multirow[t]{5}{*}{20} \\
\hline & $7.30-8.30$ & 10 & 9 & 90 & & 2 & 20 & \\
\hline & $8.30-9.30$ & 10 & 7 & 70 & & 1 & 10 & \\
\hline & $9.30-10.30$ & 10 & 8 & 80 & & 3 & 30 & \\
\hline & $10.30-11.30$ & 10 & 8 & 80 & & 2 & 20 & \\
\hline \multirow[t]{5}{*}{ White } & $6.30-7.30$ & 10 & 7 & 70 & \multirow[t]{5}{*}{70} & 1 & 10 & \multirow[t]{5}{*}{32} \\
\hline & $7.30-8.30$ & 10 & 8 & 80 & & 2 & 20 & \\
\hline & $8.30-9.30$ & 10 & 6 & 60 & & 3 & 30 & \\
\hline & $9.30-10.30$ & 10 & 7 & 70 & & 4 & 40 & \\
\hline & $10.30-11.30$ & 10 & 7 & 70 & & 1 & 10 & \\
\hline \multirow[t]{5}{*}{ Pink } & $6.30-7.30$ & 10 & 6 & 60 & \multirow[t]{5}{*}{74} & 3 & 30 & \multirow[t]{5}{*}{22} \\
\hline & $7.30-8.30$ & 10 & 9 & 90 & & 2 & 20 & \\
\hline & $8.30-9.30$ & 10 & 6 & 80 & & 1 & 10 & \\
\hline & $9.30-10.30$ & 10 & 7 & 70 & & 3 & 30 & \\
\hline & $10.30-11.30$ & 10 & 7 & 70 & & 2 & 20 & \\
\hline \multirow[t]{5}{*}{ Yellow } & $6.30-7.30$ & 10 & 7 & 70 & \multirow[t]{5}{*}{72} & 3 & 30 & \multirow[t]{5}{*}{24} \\
\hline & $7.30-8.30$ & 10 & 9 & 90 & & 2 & 20 & \\
\hline & $8.30-93.0$ & 10 & 8 & 80 & & 2 & 20 & \\
\hline & $9.30-10.30$ & 10 & 6 & 60 & & 1 & 10 & \\
\hline & & 10 & 6 & 60 & & 4 & 40 & \\
\hline
\end{tabular}

Table.4 Number of days taken for completion of flowering phase (Single flower) in nerium (Nerium oleander L.) cultivars

\begin{tabular}{|c|c|c|c|c|}
\hline Cultivars & $\begin{array}{c}\text { Number of days for } \\
\text { inflorescence initiation } \\
\text { to bud initiation }\end{array}$ & $\begin{array}{c}\text { Number of days } \\
\text { for bud initiation } \\
\text { to balloon stage }\end{array}$ & $\begin{array}{c}\text { Number of days } \\
\text { after anthesis to } \\
\text { withering of } \\
\text { flower }\end{array}$ & $\begin{array}{c}\text { Total } \\
\text { number of } \\
\text { days }\end{array}$ \\
\hline Red & 6.33 & 12.00 & 7.33 & 29.66 \\
\hline White & 6.40 & 10.80 & 6.73 & 27.93 \\
\hline Pink & 5.73 & 11.00 & 7.46 & 28.20 \\
\hline Yellow & 6.38 & 10.81 & 6.90 & 27.53 \\
\hline & & & & \\
\hline Mean & 6.21 & 11.15 & 7.11 & 28.33 \\
\hline SEd & 0.23 & 0.43 & 0.43 & 0.27 \\
\hline CD(p=0.05) & 0.52 & 0.95 & 2.41 & 0.60 \\
\hline
\end{tabular}


Table.5 Total number of inflorescence plant ${ }^{-1}$ and Number of flowers per inflorescence at $6^{\text {th }}$ month after planting in nerium (Nerium oleander L.) cultivars

\begin{tabular}{|c|c|c|}
\hline \multirow{2}{*}{ Cultivars } & \multicolumn{2}{|c|}{ Month after planting } \\
\cline { 2 - 3 } $\mathbf{6}^{\text {th }}$ & $\begin{array}{c}|c| \\
\text { Number of inflorescence } \\
\text { plant }^{-1}\end{array}$ & $\begin{array}{c}\text { Number of flowers } \\
\text { inflorescence }\end{array}$ \\
\hline Red & 13.00 & 68.93 \\
\hline White & 17.53 & 64.03 \\
\hline Pink & 21.86 & 70.86 \\
\hline Yellow & 12.53 & 65.46 \\
\hline Mean & 16.23 & 67.32 \\
\hline SEd & 0.65 & 2.68 \\
\hline CD (p= 0.05) & 1.41 & 5.85 \\
\hline
\end{tabular}

Table.6 Flower diameter, corolla tube length, and pedicel length in nerium (Nerium oleander L.) cultivars

\begin{tabular}{|c|c|c|c|}
\hline Cultivars & $\begin{array}{c}\text { Flower diameter } \\
(\mathbf{c m})\end{array}$ & $\begin{array}{c}\text { Corolla tube length } \\
(\mathbf{c m})\end{array}$ & $\begin{array}{c}\text { Pedicel length } \\
(\mathbf{c m})\end{array}$ \\
\hline Red & 4.84 & 1.98 & 0.64 \\
\hline White & 4.71 & 1.76 & 0.66 \\
\hline Pink & 5.04 & 2.15 & 0.75 \\
\hline Yellow & 4.74 & 1.84 & 0.61 \\
\hline Mean & 4.83 & 1.93 & 0.67 \\
\hline SEd & 0.08 & 0.06 & 0.04 \\
\hline CD (p= 0.05) & 0.18 & 0.14 & NS \\
\hline
\end{tabular}

Table.7 Length of androecium and gynoecium in nerium (Nerium oleander L.) cultivars

\begin{tabular}{|c|c|c|}
\hline Cultivars & $\begin{array}{c}\text { Length of androecium } \\
(\mathbf{c m})\end{array}$ & $(\mathbf{c m})$ Length of gynoecium \\
\hline Red & 2.59 & 1.29 \\
\hline White & 2.54 & 1.24 \\
\hline Pink & 2.47 & 1.40 \\
\hline Yellow & 2.44 & 1.30 \\
\hline Mean & $\mathbf{2 . 5 1}$ & $\mathbf{1 . 3 1}$ \\
\hline SEd & 0.02 & 0.01 \\
\hline CD (p= 0.05) & 0.04 & 0.04 \\
\hline
\end{tabular}


Table.8 Fruit length, fruit diameter and number of seeds fruit ${ }^{-1}$ in nerium (Nerium oleander L.) cultivars

\begin{tabular}{|c|c|c|c|}
\hline Cultivars & Fruit length $\mathbf{( c m )}$ & Fruit diameter $\mathbf{( m m )}$ & $\begin{array}{c}\text { Number of seeds fruit } \\
\mathbf{1}\end{array}$ \\
\hline Red & 15.68 & 7.28 & 266.06 \\
\hline White & 14.89 & 6.49 & 209.06 \\
\hline Pink & 13.62 & 8.81 & 279.00 \\
\hline Yellow & 14.09 & 6.87 & 217.36 \\
\hline Mean & 14.77 & 7.36 & 242.87 \\
\hline SEd & 0.56 & 0.14 & 14.75 \\
\hline CD (p= 0.05) & 1.23 & 0.54 & 32.14 \\
\hline
\end{tabular}

Table.9 Pollen morphology of nerium (Nerium oleander L.) cultivars

\begin{tabular}{|c|c|c|c|c|c|}
\hline Cultivars & $\begin{array}{c}\text { Equatorial } \\
\text { length }(\boldsymbol{\mu m})\end{array}$ & $\begin{array}{c}\text { Polar length } \\
(\boldsymbol{\mu m})\end{array}$ & E/P ratio & $\begin{array}{c}\text { Length of } \\
\text { exine }(\boldsymbol{\mu m})\end{array}$ & $\begin{array}{c}\text { Length of } \\
\text { intine }(\boldsymbol{\mu m})\end{array}$ \\
\hline Red & 43.00 & 38.05 & 1.13 & 2.14 & 0.39 \\
\hline white & 46.24 & 41.91 & 1.10 & 2.35 & 0.31 \\
\hline Pink & 46.55 & 40.37 & 1.15 & 2.46 & 0.29 \\
\hline Yellow & 48.98 & 42.65 & 1.14 & 2.37 & 0.33 \\
\hline Mean & 46.19 & 40.75 & 1.13 & 2.33 & 0.33 \\
\hline SEd & 1.79 & 1.57 & 0.04 & 0.29 & 0.013 \\
\hline $\begin{array}{c}\text { CD } \\
(\mathbf{p = 0 . 0 5})\end{array}$ & 3.90 & $\mathrm{NS}$ & NS & 0.65 & 0.028 \\
\hline
\end{tabular}

Table.10 Number of pollen grains anther ${ }^{-1}$, number of pollen grains flower ${ }^{-1}$, number of ovules flower $^{-1}$ and pollen ovule ratio in nerium (Nerium oleander L.) cultivars

\begin{tabular}{|c|c|c|c|c|}
\hline Cultivars & $\begin{array}{c}\text { No. of Pollen } \\
\text { grains anther }\end{array}$ & $\begin{array}{c}\text { No. of pollen }_{-\mathbf{1}} \\
\text { grains flower }\end{array}$ & $\begin{array}{c}\text { No. of ovules } \\
\text { flower }^{-1}\end{array}$ & $\begin{array}{c}\text { Pollen ovule } \\
\text { ratio }\end{array}$ \\
\hline Red & 2866.67 & 14066.67 & 333.67 & 47.02 \\
\hline White & 2600.00 & 13000.00 & 379.86 & 34.39 \\
\hline Pink & 3100.00 & 14600.00 & 386.33 & 36.40 \\
\hline Yellow & 2716.61 & 14000.00 & 336.60 & 42.47 \\
\hline Mean & 2820.82 & 13916.67 & 359.12 & 40.07 \\
\hline SEd & 111.83 & 548.10 & 25.20 & 12.42 \\
\hline CD(p=0.05) & 243.67 & NS & NS & NS \\
\hline
\end{tabular}



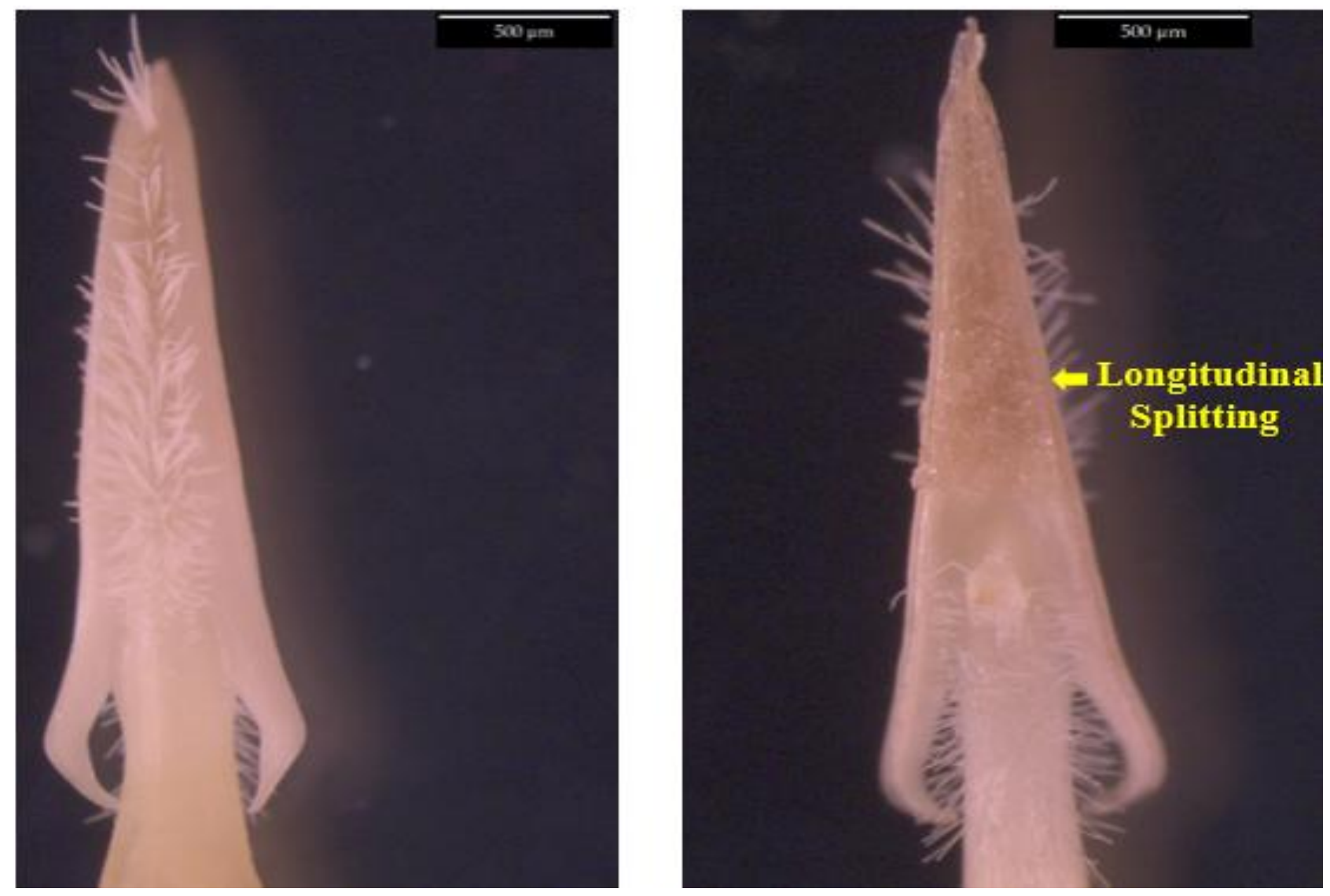

Fig:1 Dorsal and ventral side view of Nerium anther
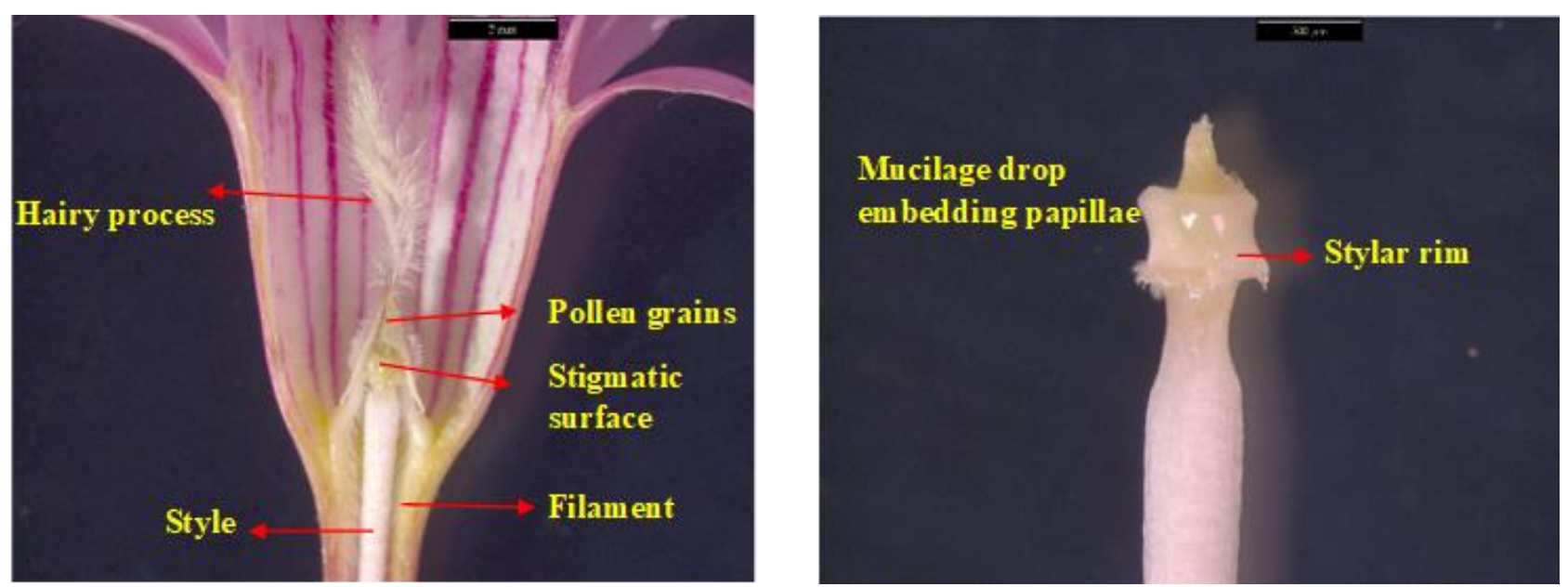

Fig: 2 Cross section of flower and stigma of Nerium flower 
Fig.3 Stages of flower development in Nerium cultivars

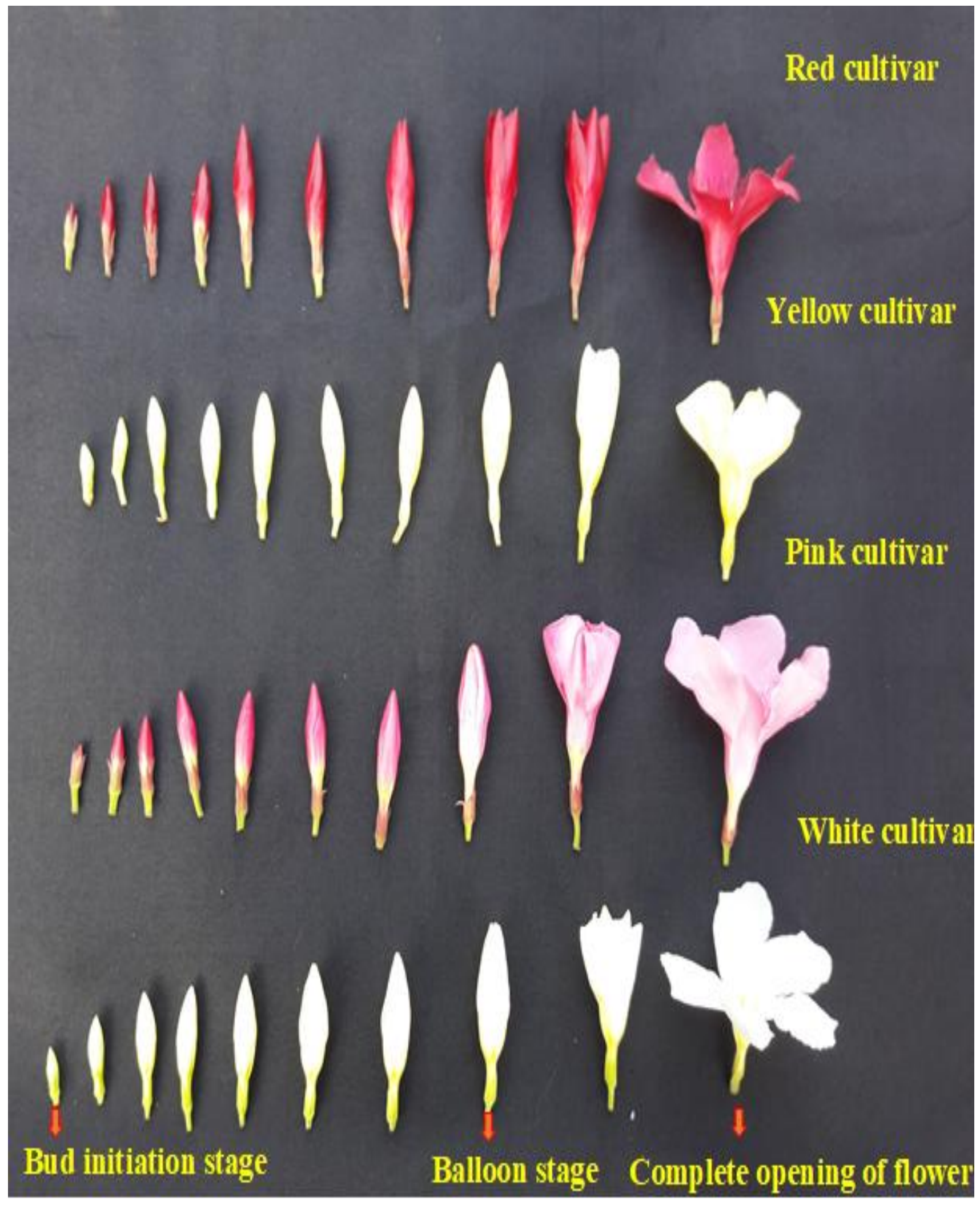


Fig.4 Pollen morphology in Nerium cultivars
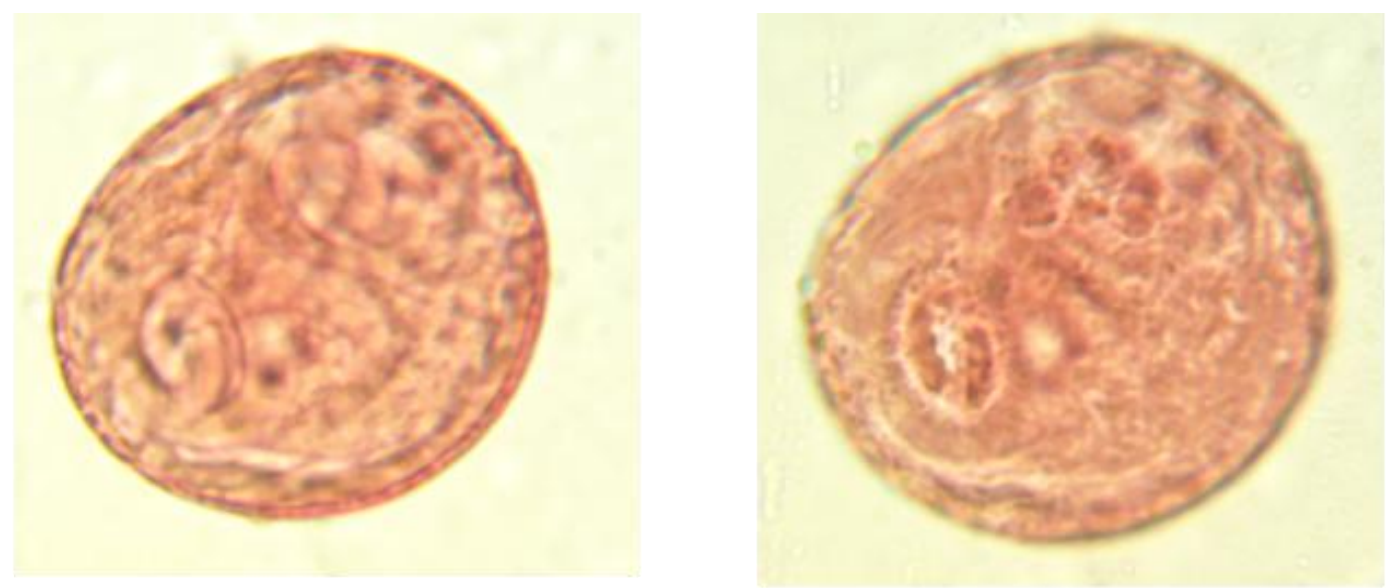

Equatorial view of Red cultivar pollen Polar view of Red cultivar pollen

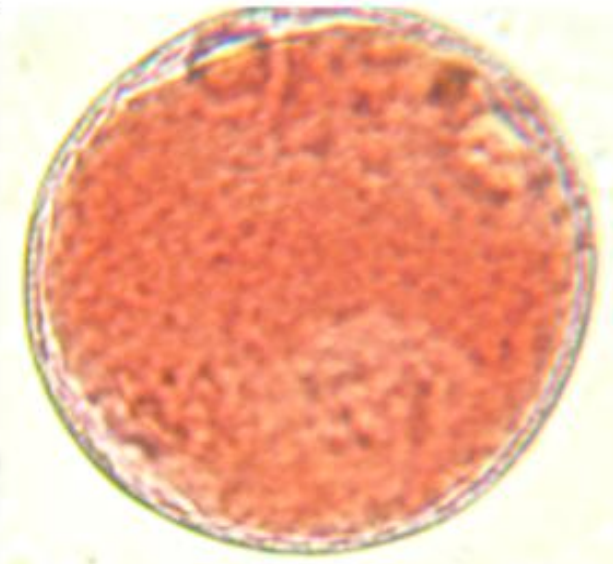

Equatorial view of Pink cultivar pollen

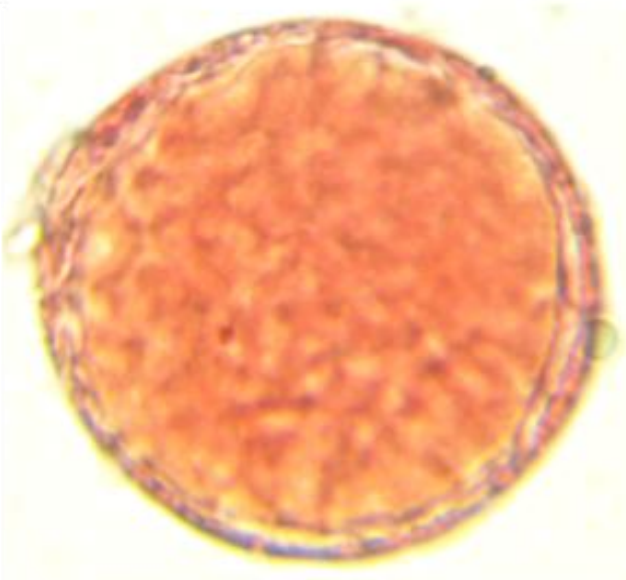

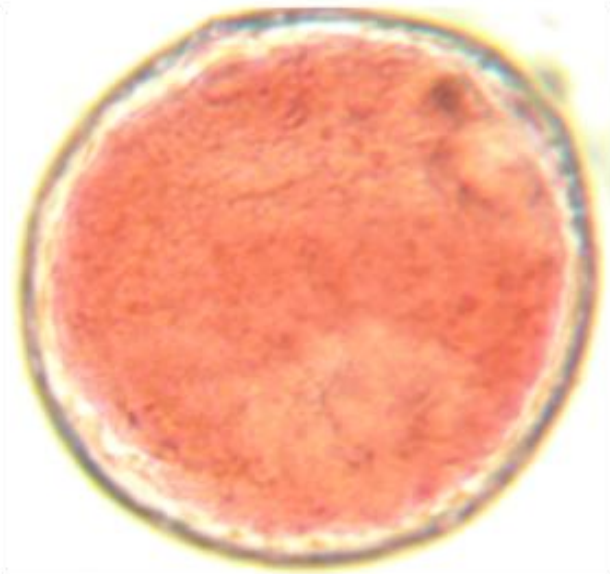

Polar view of Pink cultivar pollen

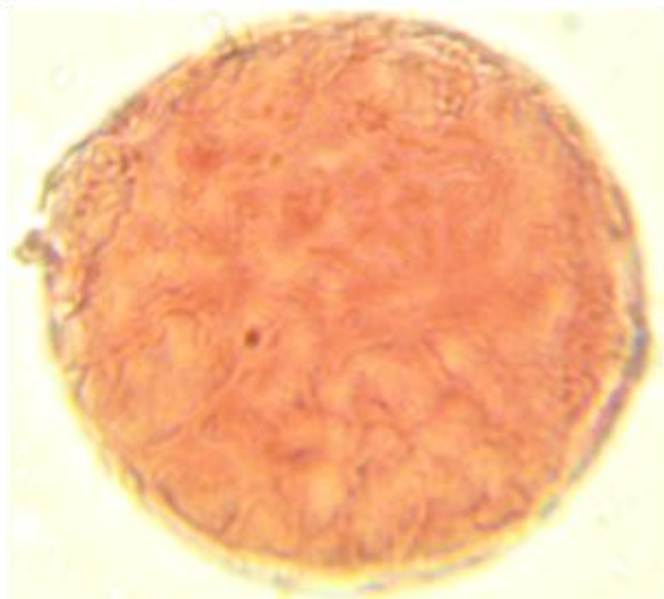

Equatorial view of Yellow cultivar pollen Polar view of Yellow cultivar pollen 
Fig.5 Ovary, ovules and pollen production in Nerium cultivars

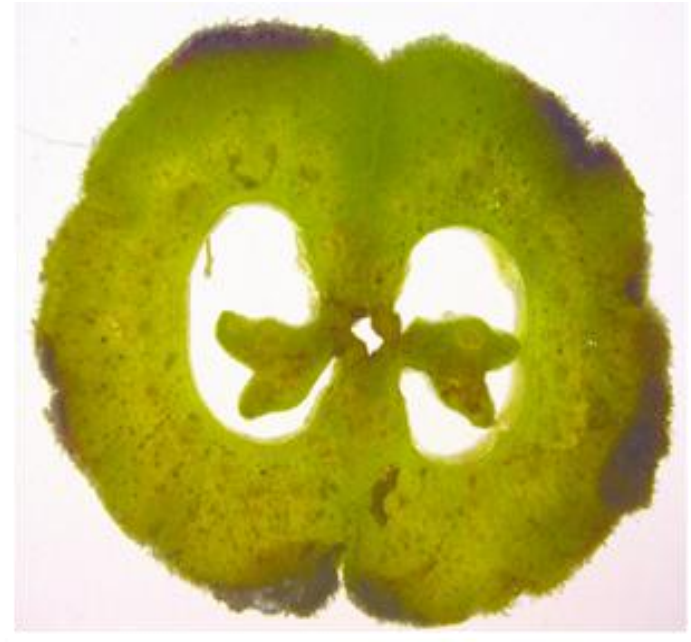

Bilocular ovary in nerium

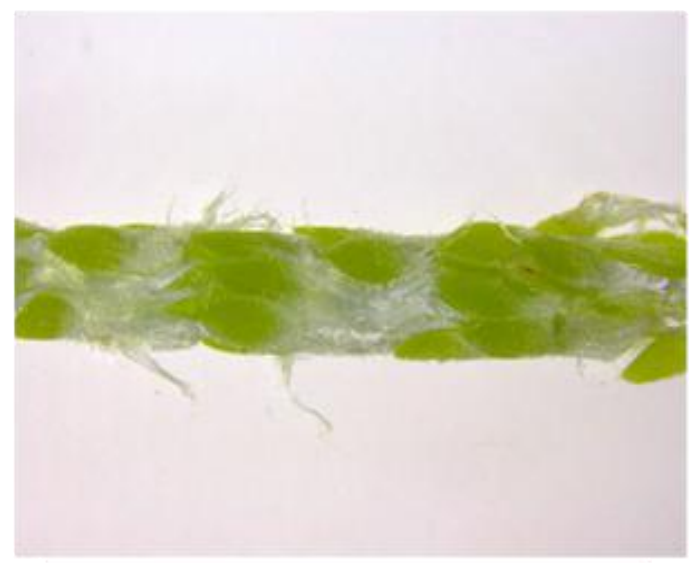

Arrangement of ovules

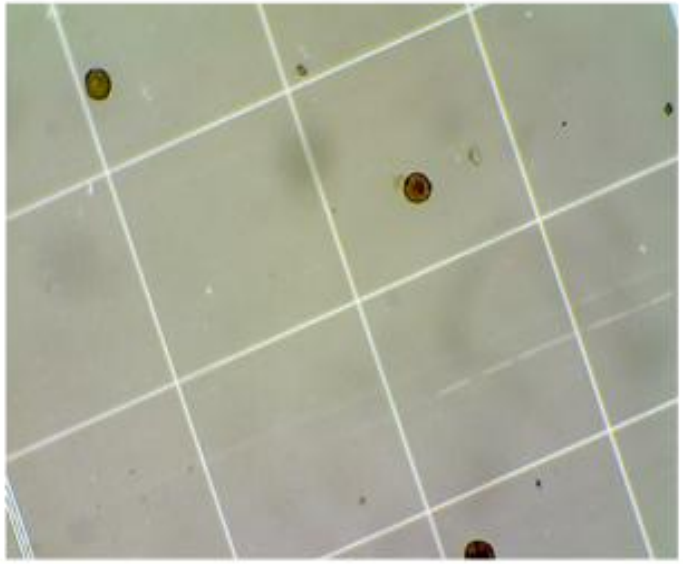

Pollen production in White cultivar

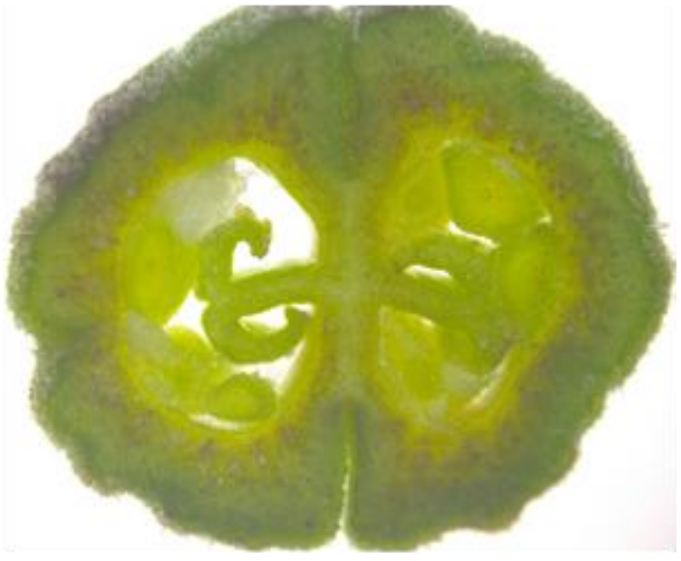

Bilocular ovary with ovules

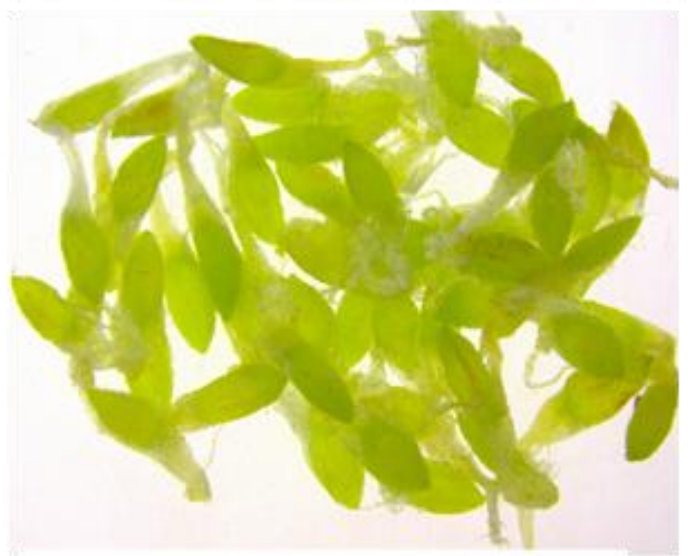

Nerium ovules

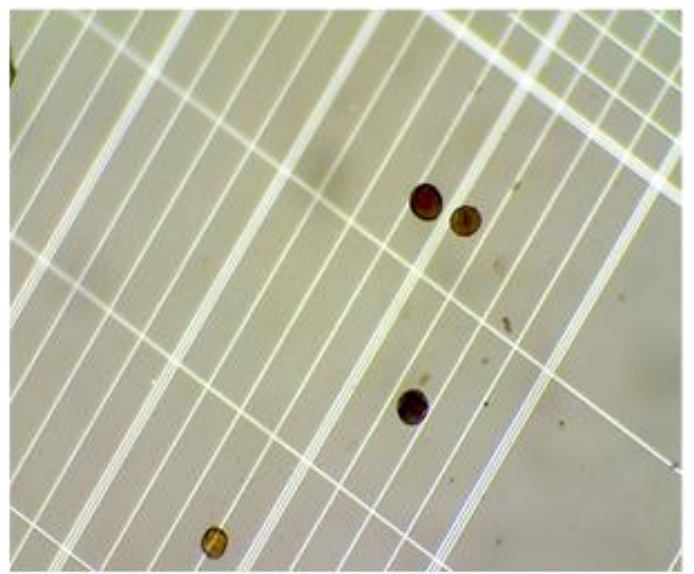

Pollen production in Pink cultivar 
This was in accordance with findings of Herrera (1989) in nerium.

The data on fruit length, fruit diameter and number of seeds per fruit are presented in Table 8 . The fruit length varied significantly among the cultivars. Among the cultivars highest fruit length of $15.68 \mathrm{~cm}$ was recorded in the Red cultivar followed by the White cultivar $(14.89 \mathrm{~cm})$ and while least in the Pink cultivar $(13.62 \mathrm{~cm})$.Among the nerium cultivars highest fruit diameter $(8.81 \mathrm{~cm})$ was recorded in the Pink cultivar followed by the Red cultivar $(7.28 \mathrm{~cm})$ and while the least in White cultivar with $6.49 \mathrm{~cm}$.

Highest number of seeds fruit ${ }^{-1}$ (279.00) was recorded in the Pink cultivar followed by Red cultivar (266.06) and while least in White cultivar (209.06). This was in agreement with observation made by Herrera (1991) and Kiran and Prasad (2014) in nerium. This was in line with findings of Herrera (1989) in nerium. Similar observation made by Kulloli and Shreekala (2009) in Rauvolfia micrantha was that each berry usually contains one and rarely two seeds.

\section{Pollen morphology and number of pollen grains}

Data on pollen morphology are presented in Table 9 figure 4. Significant variations were found on, equatorial length, length of exine, length of intine among the different nerium cultivars. Research on the morphological characteristics of pollen is of great significance in taxonomy, phylogeny and paleobotany. Because pollen grains have a definite shape, size, color, and structure for each species, genus and family. Characteristics of pollen grains size and shape of pollen grains as well as characteristics of exine layer may be useful in identifying certain species and cultivars (Radovic et al., 2016).
Among the cultivars the highest equatorial length $(48.98 \mu \mathrm{m})$ and polar length $(42.65 \mu \mathrm{m})$ was recorded in yellow cultivar whereas, least equatorial length $(43.00 \mu \mathrm{m})$ and polar length $(38.05 \mu \mathrm{m})$ was recorded in Red cultivar. Similar observation was made in Rauvolfia micrantha by Kulloli and Shreekala (2009). This was in agreement with observation made by Usman et al., 2016 in Rauvolfia serpentina that pollen grains were found in two different size classes, mostly $82.5 \pm 5 \mu \mathrm{m}$ and rarely $52.3 \pm 5 \mu \mathrm{m}$.

Among the cultivars the highest length of exine $(2.46 \mu \mathrm{m})$ was recorded in Pink cultivar followed by Yellow cultivar $(2.37 \mu \mathrm{m})$ while least length of exine was recorded in Red cultivar $(2.14 \mu \mathrm{m}$. This was in agreement with the observation made by Amier (2015) in hydrophytes who stated that equatorial length ranged between $18.6 \pm 1.0$ to $95.7 \pm 9.5 \mu \mathrm{m}$. The similar observation made by Azzazy (2016) with Lamiaceae family. The length of exine and intine of nerium cultivars pollens ranged between 2.14 to $2.46 \mu \mathrm{m}$ and 0.29 to $0.39 \mu \mathrm{m}$ respectively. This was in line with observation made by Poyraz and Ataşlar (2010) in Velezia sp. Among the cultivars the highest length of intine was recorded in Red cultivar $(0.39 \mu \mathrm{m})$ followed by yellow cultivar $(0.33 \mu \mathrm{m})$ and the least in Pink cultivar $(0.29 \mu \mathrm{m})$. Among the cultivar highest radius of pollen was observed in Yellow cultivar and less radius of the pollen was observed in Red cultivar

\section{Number of ovules and pollen ovule ratio}

Data pertaining to the performance of different nerium cultivars for number of pollen grains per anther, number of pollen grains per flower, number of ovules per flower and pollen ovule ratio has been presented in Table 10 figure 5. Highest number of pollen grains per anther was 
recorded in Pink cultivar (3100.00) followed by red cultivar (2866.67) and the least in white cultivar (2600.00). Among the cultivars maximum number of pollen grains per flower was recoded highest in Pink cultivar (14600.00) followed by Red cultivar (14066.67) and the least in White cultivar (13000.00). Among the cultivars highest number of ovule per flower (386.33) was recorded in Pink cultivar this was followed by White cultivar (379.86) while least in red cultivar (333.67). Among the cultivars the highest number of pollen ovule ratio (47.02) was recorded in Red cultivar followed Yellow cultivars (42.47) and the least in White cultivar (34.39). This was in accordance with observation made by Herrera (1989) in nerium. Similar findings made by (Usman et al., 2016) in Rauvolfia serpentina reported that $225 \pm 20$ pollen grains anther- 1 and 1125 \pm 100 pollen grains flower- 1 . This is was agreement with findings of Kulloli and shreekala (2009) in Rauvolfia micrantha.

\section{References}

Albornoz, A. Fernandez, M. Vilchez, J. Fernandez, C. and L.Martinez. 2014. Effect of paclobutrazol on growth oleander (Nerium oleander L.) plant in nursery. Rev. Fac. Agron, Supl. 1:301311.

Amir, Y. A. 2015. Morphological studies of the pollen grains for some hydrophytes in coastal Mediterranean lakes. Egyptian Journal of Basic and Applied LifeScience, 2: 132-138.

Anandhi, S. 2012. Enhancement of variability in Gloriosa spp. through mutation and hybridization techniques. Ph.D., (Horti) Thesis, Tamil Nadu Agricultural University, Coimbatore. P.No:36

Anandhi, S.and K. Rajamani.2012. Reproductive biology of Gloriosa superba. Open Access Journal of Medicinal and Aromatic Plants, 3(2): 5-
11.

Azzazy, M. F. 2016. Systematic importance of pollen morphology of some plants of Lamiaceae. Current Botany, (7): 5-10.

Barrios, B. and S. Koptur. 2011. Floral biology and breeding system of Angadenia berteroi (Apocynaceae) why do flowers of the pineland golden Trumpet produce few fruits, Int. J Plant Sci, 172(3):378-385.

Herrera, J. 1989. The reproductive biology of a riparian Mediterranean shrub, Nerium oleander L. (Apocynaceae). Botanical journal of the Linnean Society, 106: 147-172.

Kiran, C. D and N. Prasad. 2014. A Review on: Nerium oleander Linn. (Kaner). IJPPR, 6(3):593-597.

Kulloli, S. K and A.K. Sreekala. 2009. Pollination Ecology of Rauvolfia micrantha Hook. F. (Apocynaceae): A Critically Endangered Medicinal Plant from the Southern Western Ghats. Phytomorphology 59: 96-101.

Mamatha, H. 1989. Studies on the problem of fruit set and its improvement in Gloriosa superba L. M.Sc., (Hort.) Thesis, University of Agricultural Sciences, Bangalore. P. No.54

Panse, N.G. and P.V. Sukhatme. 1985. In: Statistical methods for Agricultural Workers, ICAR Publication, 158.

Poyraz, I.E. and E. Ataslar. 2010. Pollen and seed morphology of Velezia $L$. (Caryophyllaceae) genus in Turkey. Turk J Agric For, 40: 441-44.

Radovic, A. Nikolic, D. Milatovic and J. Trajkovic. 2016. Investigation of pollen morphological characteristics in some quince (Cynodia oblonga Mill) cultivars. Genus in Turkey. Turk $J$ Bot, 34: 179-190.

Ranchana P. 2013. Evaluation of tuberose genotypes for development of F1hybrids for quantitative, qualitative characters and nematode resistance. 
Ph.D. (Hort.) Thesis, Tamil Nadu agriculture university Coimbatore, P.No. 65.

Sathiamoorty, S. 1973. Preliminary investigations on breeding potential of some banana clones. M.Sc. (Hort.) Thesis, Tamil Nadu Agricultural University, Coimbatore, P. 29.

Sihag, R.C., and N. Wadhwa. 2011. Floral and reproductive biology of Sarpagandha Rauvolfia serpentina (Gentianales: Apocynaceae) in semiarid environment of India. Journal of Threatened Taxa, 3(1): 1432-1436.
Usmani, G., Mandal. A.K., Chawaan P.H. and Y. Mishra. 2016. Reproductive biologyand breeding system in Rauvolfia serpentine (L.) Benth. Ind $J$ Plant Physiol, 21(1): 31-36.

Yadav, P. Bharadwaj, N.P.S., Yedukondalu, M. and A. Ravi Kumar. 2013. Phytochemical evaluation of Nyctanthes arbortristis, Nerium oleander and Catharathnus roseus. Indian Journal of Research in Pharmacy and Biotechnology, 1(3): 133-137

\section{How to cite this article:}

Parashuram, M., K.R. Rajadurai, S. Haripriya and John Joel, A. 2019. Reproductive Biology Studies in Nerium Cultivars (Nerium oleander L.). Int.J.Curr.Microbiol.App.Sci. 8(07): 377392. doi: https://doi.org/10.20546/ijcmas.2019.807.047 